\title{
Citizen Recommendation for Social Media-Based Government Application Development: A Design Science Approach
}

\author{
${ }^{1,2}$ Evaristus Didik Madyatmadja, ${ }^{2}$ Edi Abdurachman, ${ }^{2}$ Ford Lumban Gaol, \\ ${ }^{3}$ Bonifasius Wahyu Pudjianto and ${ }^{4}$ Manik Hapsara \\ ${ }^{I}$ Department of Information Systems, School of Information Systems, \\ Bina Nusantara University, Jakarta, Indonesia 11480, Indonesia \\ ${ }^{2}$ Department of Computer Science, BINUS Graduate Program-Doctor of Computer Science, \\ Bina Nusantara University, Jakarta, Indonesia 11480, Indonesia \\ ${ }^{3}$ Indonesian Creative Economy Agency, Jakarta, Indonesia \\ ${ }^{4}$ School of Engineering and Information Technology, University of New South Wales, Australia
}

Article history

Received: 12-04-2018

Revised: 24-09-2018

Accepted: 22-10-2018

Corresponding Author: Evaristus Didik Madyatmadja Department of Information Systems, School of Information Systems, Bina Nusantara University, Jakarta, Indonesia 11480, Indonesia

Email: emadyatmadja@binus.edu

\begin{abstract}
The sustained social and economic phenomenon will affect the coming years, such as the increased cultural and religious diversity, population growth and changes in consumption and lifestyle. This condition will create various challenges to the public service. In providing the initiative on e-government, in this case is e-government based on social media, the government has invested in resources, energy, time and minds with the belief that it will improve the service quality to citizens. The purpose of this initiative is for citizens to use social media that allows them to access information about the condition of their city. This social media application offers the benefits of a communication channel between the community and the government or parties which has a public interest. Through this application, people can complain about various public services. Therefore, this research aimed to allow citizens to provide feedback on the development of ongoing social media-based e-government applications and to build and propose the appropriate architecture needed to develop a social media-based egovernment application.
\end{abstract}

Keywords: e-Government, Social Media, Public Service

\section{Introduction}

According to Gartner Group, e-government is a continuous optimization of public services, participation and governance by altering internal and external relationships through technology, the internet and new media. One of connections through this technology and new media can be through social media. Social media is rapidly growing because it supports some of the important social needs which help to serve communication needs. The current focus of egovernment is the efficiency of information technology and the quality improvement of public services (Centeno et al., 2005). Hence, the technology will play an extensive role in the lives of citizens, thereby altering public expectations of government services (Saha, 2008). The government needs to understand how social media supports communities and businesses in fulfilling social needs through communication in social networks (Roy, 2014). This makes a possibility to easily use inter- community networks because it is interactive and not only using text but also video and audio.

The use of various social media sites and tools by public, business and public organizations, makes government thinks carefully about how governments can benefit from the use of social media in rebuilding their relationships with communities and increasing participation and public involvement levels (Khasawneh and Abu-Shanab, 2013). This is important for e-government site because it is considered a public site and the public is always expected to visit the site. However, social network is a site where people interact and enter the site so that the relationship between government and community will be closer (Atari et al., 2011).

Furthermore, e-government application is intended to improve the performance and welfare of civil servants or government employees who are working in several institutions as public servants (Hardjaloka, 2014). Society, who is the customer of the public service, has a hope that the performance of public service providers 
will be more professional and able to satisfy the community (Mustafid and Sugiharto, 2014).

Consequently, various government initiatives are implemented with the purpose to build service that focuses on public needs and to provide better access to government services. The latest technology that aims to coordinate and analyze data is important, but e-government initiatives need to involve citizen participation as well as urban communities (Pusbindiklatren, 2015).

The concept of open government was introduced in 2009. Since then, many governments have begun to follow that path. The government still needs a great effort to exploit the emerging technology in open government that are social networks. Social networks are very useful in the implementation of electronic government in the form of problems related to public complaints in the city.

The purpose of this research allows citizens to provide feedback on the development of ongoing social media-based e-government applications because (a) applications are required for the benefit of open data availability (TWH, 2011) and (b) most governments do not have the capacity to build applications to serve the public needs. However, public suggestions may be a solution to overcome these shortcomings, the research gap is perceived as a lack of knowledge of how to build social media-based e-government application that allow communities to share their knowledge to support the development of application.

So, the research problem is: What kind of architecture is needed in building e-government application based on social media? This research aimed to build and communicate the appropriate architecture that is needed and can be easily replicated to develop a social media-based e-government application.

\section{Design Science Approach for Platform Application Development}

The scenario of application platform development is the initial process that begins with the public demand through collected questionnaires (Fig. 1). The government is also responsible for the application development. The society can also become the tester and evaluator for the submitted apps by reviewing, giving developers an increased possibility, or giving ratings. The literature has uncovered several variations of the scheme of the design science approach and has been adopted in this study (Peffers, 2007).

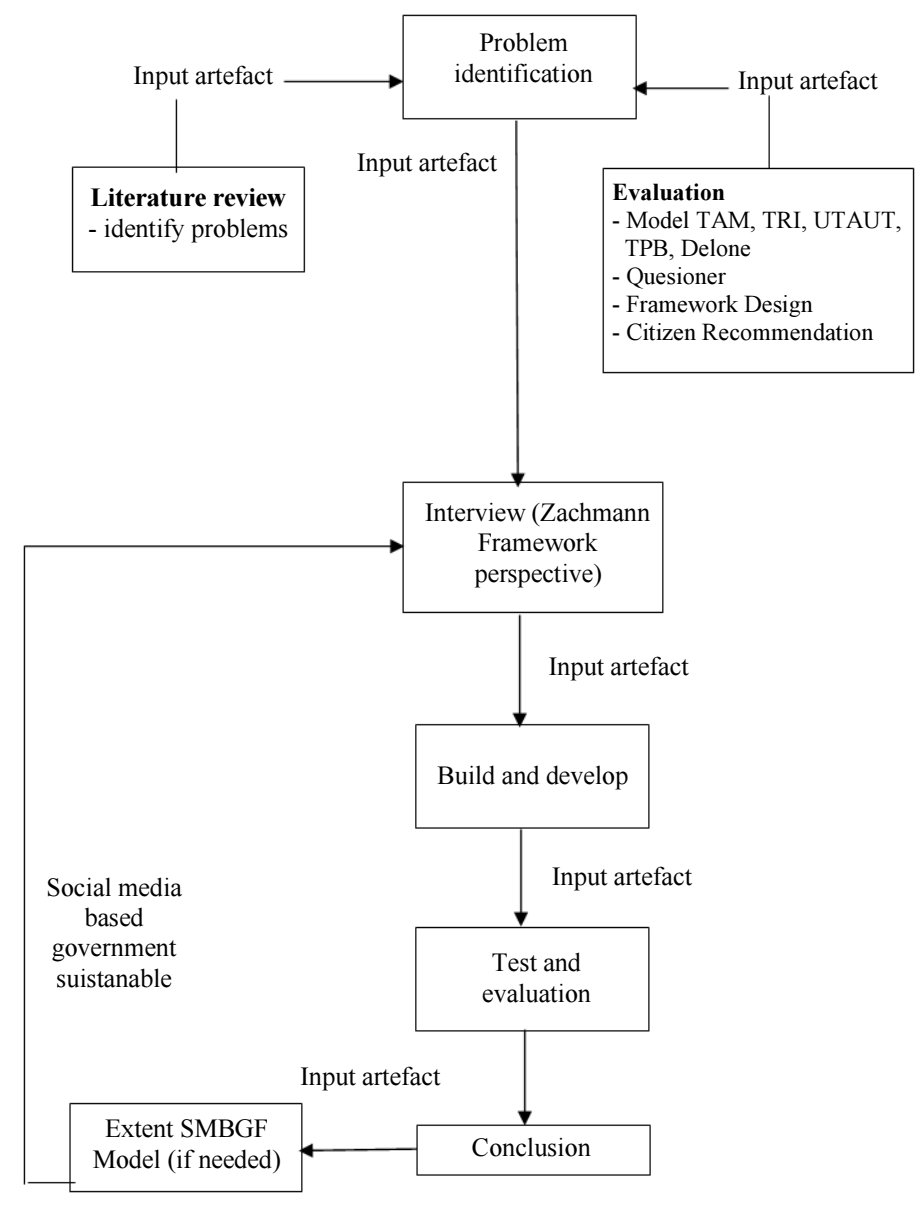

Fig. 1: Research process 


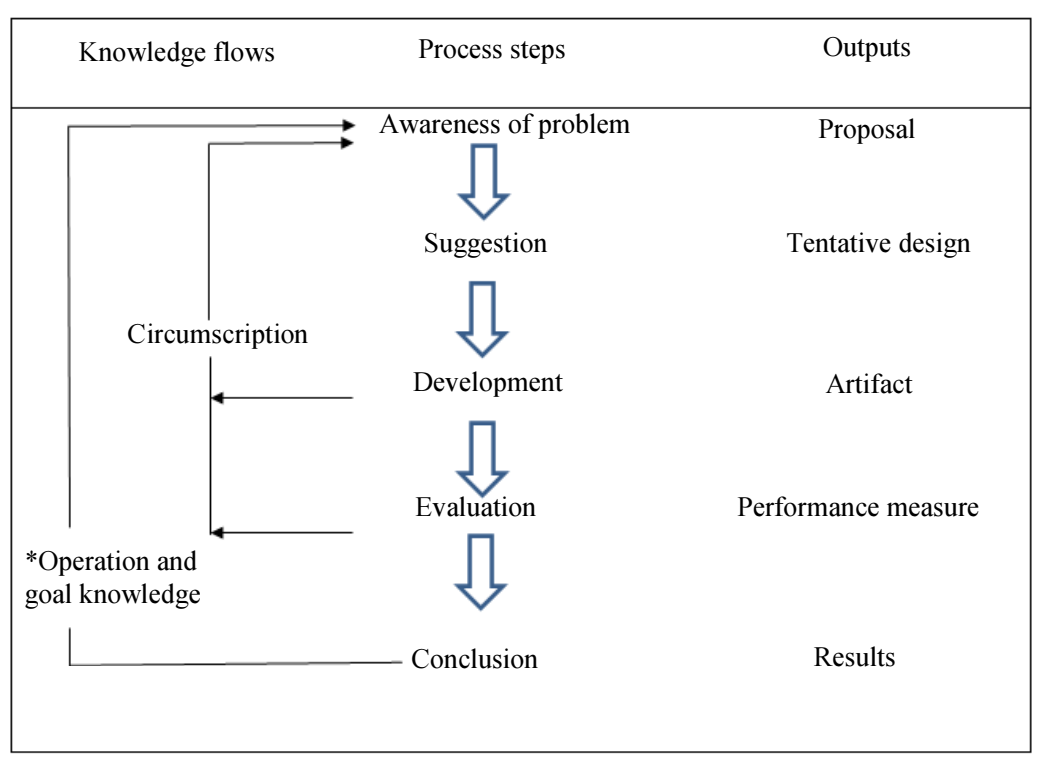

Fig. 2: Design research methodology (Vaishnavi and Kuechler, 2004)

The design science research methodology incorporates five phases of design and is implemented by using a repetitive design cycle that assists sustainable development as the main attribute (Vaishnavi and Kuechler, 2004) and is adapted from (Takeda et al., 1990) that based on the experimental point of view (Fig. 2). The first phase is the issue of awareness in research design and then followed by the suggestion as the solution of tentative design. The third phase is the development used for lesson and improvement after user feedbacks. The most important is the evaluation of artifacts as the fourth stage, in which a performance measure of the knowledge base can be applied to test the usefulness of the artifact. The research methodology can produce a more effective design when combined with other research methodologies (Nunamaker, 1990). The design is represented as a process and the steps involved in the design process use design as research to generate knowledge. The design methodology is recommended as an information systems research framework (March and Smith, 1995; Hevner et al., 2004).

\section{Applying Research Design}

The iterative process has five steps in design process which are awareness of problem, suggestion, development, evaluation and conclusion (Vaishnavi and Kuechler, 2004).

Awareness of Problem identifies factors affecting the development of e-Government services by conducting pilot studies in the form of surveys based on end-user feedback and evaluating the adoption and acceptance of social media-based e-Government services in Indonesia. The main purpose of this evaluation is to investigate how citizens/users of social media based e-Government see the quality of current social media based e-Government applications and to identify requirements and suggestions for improvements from the application user feedback.

Suggestion aims to examine several tentative solutions on how the problem is identified in the previous step, which is iteration 1. It can be solved by becoming more specific and by determining the definite influence from the quality of social media based e-Government services through the creation and design accordingly. Analyzing the current social media-based e-Government service design process can help investigate the development of the social media-based e-Government service design process. It is derived from inputs, field observations and suggestions from interviewed respondents. The respondents are government employees who help the social media based e-Government project during the development phase of government services.

The interview involved six perspectives of Zachman Framework which are executive perspective, business management perspective, architect perspective, engineer perspective, technician perspective and enterprise perspective (Fig. 3).

Development is performed by building and designing artifact of e-Government that based on Social Media, which is a collaborative platform for communication design tools that help users in this case government employees to innovate. The artifact consists of the proposed social media-based e-Government, so the proposal more understands the dynamic process of eGovernment service design based on social media and its interest in line with the development of e-Government. This artifact is a proposed application supporting collective innovation and changes that have occurred in recent years according to the needs of the user community that has not been following community expectations (Fig. 1). 


\begin{tabular}{|c|c|c|c|c|c|c|}
\hline $\begin{array}{r}\text { Scope } \\
\text { (Contextual) }\end{array}$ & $\begin{array}{l}\text { List of things } \\
\text { important to the } \\
\text { business }\end{array}$ & $\begin{array}{l}\text { List of processes } \\
\text { business } \\
\text { performed }\end{array}$ & $\begin{array}{c}\text { List of locations } \\
\text { in which business } \\
\text { operates }\end{array}$ & $\begin{array}{l}\text { List of } \\
\text { organizations } \\
\text { important to the } \\
\text { business }\end{array}$ & $\begin{array}{l}\text { List of events } \\
\text { significant to the } \\
\text { business }\end{array}$ & $\begin{array}{l}\text { List of business } \\
\text { goals and } \\
\text { strategies }\end{array}$ \\
\hline $\begin{array}{r}\text { Business model } \\
\text { (Conceptual) }\end{array}$ & $\begin{array}{l}\text { CONOP model } \\
\text { or context data }\end{array}$ & $\begin{array}{l}\text { CONOP model or } \\
\text { context function }\end{array}$ & $\begin{array}{l}\text { CONOP model or } \\
\text { context network }\end{array}$ & $\begin{array}{l}\text { CONOP model } \\
\text { or context } \\
\text { human interface }\end{array}$ & $\begin{array}{l}\text { Business master } \\
\text { schedule: MS } \\
\text { project, OPLAN }\end{array}$ & $\begin{array}{l}\text { Business } \\
\text { masterplan: text, } \\
\text { charts of } \\
\text { diagrams }\end{array}$ \\
\hline $\begin{array}{r}\text { System model } \\
\text { (Logical) }\end{array}$ & $\begin{array}{l}\text { Data is part of } \\
\text { applications } \\
\text { architecture } \\
\text { SOS models }\end{array}$ & $\begin{array}{l}\text { Applications } \\
\text { architecture } \\
\text { SOS models }\end{array}$ & $\begin{array}{l}\text { Applications } \\
\text { architecture SOS } \\
\text { models include } \\
\text { NCO nodes }\end{array}$ & $\begin{array}{l}\text { Human interface } \\
\text { is part of } \\
\text { applications } \\
\text { architecture SOS } \\
\text { models }\end{array}$ & $\begin{array}{c}\text { Time sequences } \\
\text { events in the } \\
\text { applications } \\
\text { architecture SOS } \\
\text { models }\end{array}$ & $\begin{array}{l}\text { Business rule } \\
\text { incorporated into } \\
\text { SOS model }\end{array}$ \\
\hline $\begin{array}{r}\text { Technology model } \\
\text { (physical) }\end{array}$ & $\begin{array}{l}\text { Architecture } \\
\text { data models }\end{array}$ & $\begin{array}{l}\text { Technology } \\
\text { platforms }\end{array}$ & $\begin{array}{l}\text { Network devices } \\
\text { and relationships } \\
\text { within boundaries }\end{array}$ & $\begin{array}{c}\text { Human Machine } \\
\text { Interface (HMI) } \\
\text { design }\end{array}$ & $\begin{array}{l}\text { Control structure } \\
\text { to system events }\end{array}$ & $\begin{array}{l}\text { Design rules } \\
\text { constrained by } \\
\text { standards }\end{array}$ \\
\hline $\begin{array}{r}\text { Detailed } \\
\text { representations } \\
\text { (out-of-context) }\end{array}$ & $\begin{array}{l}\text { Data definitions } \\
\text { by physical data } \\
\text { models }\end{array}$ & $\begin{array}{l}\text { Built and coded } \\
\text { on specific } \\
\text { technology } \\
\text { platforms }\end{array}$ & $\begin{array}{l}\text { Network } \\
\text { architecture and } \\
\text { devices to node } \\
\text { specifications }\end{array}$ & $\begin{array}{l}\text { HMI to specific } \\
\text { platforms and } \\
\text { technologies }\end{array}$ & $\begin{array}{c}\text { Timing definitions } \\
\text { on specific } \\
\text { platforms and } \\
\text { technologies }\end{array}$ & $\begin{array}{l}\text { Building rules } \\
\text { constrained by } \\
\text { technology } \\
\text { standards }\end{array}$ \\
\hline $\begin{array}{r}\text { Functioning } \\
\text { enterprise }\end{array}$ & $\begin{array}{c}\text { Store data } \\
\text { values in actual } \\
\text { databases }\end{array}$ & $\begin{array}{l}\text { Operational } \\
\text { instructions }\end{array}$ & $\begin{array}{l}\text { Send and receive } \\
\text { messages }\end{array}$ & $\begin{array}{l}\text { Personal working } \\
\text { roles and } \\
\text { responsibilities }\end{array}$ & $\begin{array}{l}\text { Operations timing } \\
\text { activities }\end{array}$ & $\begin{array}{l}\text { Operations } \\
\text { constrained by } \\
\text { standards }\end{array}$ \\
\hline & What & How & Where & Who & When & Why \\
\hline
\end{tabular}

Fig. 3: Zachman framework (Zachman, 1987)

\section{Defining Objectives for a Solution}

In the last ten years, the implementation of egovernment in Indonesia shows various programs that run by the government in departments and agencies experiencing various obstacles and challenges. The survey by Google and Ipsos MediaCT (Media Content and Technology Research Specialists) stated that Tangerang people who are using social media are large enough. However, this condition is not in line with the user participation in social media-based e-government, which about $1 \%$ of Tangerang population (Wirmansyah, 2018). It is supported by (Bagaeen, 2006) that stated public participation on the application is still low. The progress has been achieved but compared to the initial plan and target as well as regional progress, the development of e-Government in Indonesia is still lagging behind (Kuswinardi, 2011).

Although e-Government research and practice are overgrowing, the use of e-government services is still low (Prabowo, 2016). In this context, low-level usage means the number of users of e-government services is low and it also means not optimal functional use and services. In filling the gap, the empirical survey research aims to develop new theoretical explanations for the problem of the low use of e-government services, by integrating existing information. Besides, how can democratic system gain benefit from the internet and the rise of social media phenomena? How should digital services be designed to benefit the society? A good citizen-centric approach can optimize the potential profit of an e-Government (Gupta, 2007). Co-design approach can make public services more efficient, understandable and better accommodate user needs and to build a sense of mutual need between users and providers (Bridge, 2012). This is supported by (DC, 2007) that stated CoDesign is a cooperative design between service users and service designers. User involvement in the early stages tends to reduce design errors and costs that associated with the error (Baek et al., 2008).

Based on reasons above, the existing problem is needed to be solved. First, the government needs to utilize new technology, especially citizen-sourcing, for creating the better design. Second, the needs to create the availability of open data through the application. Third is the need to increase the relation between society and government through the improvement of social relation. All this can be achieved by involving the citizen in developing social media-based e-government applications. Citizen's input not only helps government reaching a new level of social relations but also provides government for the extensive development and application testing at minimal cost.

Enterprise Architecture transforms broader principles, capabilities and goals that defined into system and process strategies that enable achieving 
company goals (Tamm et al., 2011). From various architecture frameworks, Zachman framework (Zachman, 1987) was chosen to guide proper identification of information system. The framework offers a logical structure whereby a company can follow to ensure the flow of information architecture is integrated with business units (Ertaul and Sudarsanam, 2005). The Zachman framework ensures accuracy and consistent results and enables to describe architecture from stakeholders' perspectives. The core of Zachman framework includes a two-dimensional matrix in which six columns represent various abstractions (data, process, location, people, time and motivation) and six lines that indicate viewers' point of view (planner, owner, designer, builder, programmer and user) (Zachman, 1987).

\section{Blueprint Design Development}

The main phase relates to the development and design of artifacts. The requirements outlined from analyzing existing processes that are currently underway and then expanded through the implementation of social media-based e-government principles. The interview was conducted to four experts in Department of Communication and Informatics Tangerang, Indonesia, which are Head of Communications and Information Technology, Head of Public Service Application Development and Head of Public Development Section. Table 1 shows the summary.

Suggestions are collected through interviews with each Department of Communication and Informatics official. All suggestions are considered to generate artifacts. Most artifacts (such as activity diagrams, use case diagrams) are generated from interviews. Entity Relationship Diagrams will change significantly by adding more entities and relations among entities to have better database design. ERD is considered as the beginning for the development of the class diagram (Fig. 4). For framework compatibility, suggestions indicated that the artifact is presented according to Zachman's description in each cell.

Table 1: The summary of artifacts development

\begin{tabular}{lll}
\hline Level & Abstraction & Data requirement \\
\hline Level 1 Objective/Scope & Data/What & Important Data \\
PLANNER'S VIEW & Function/How & Important Business Process \\
& People/Who & Stakeholder Analysis \\
& Time/When & Important Event \\
& Motivation/Why & Business Purpose \\
Level 2 Business Conceptual Model & Data/What & Entity Relationship Diagram (Fig. 4) \\
OWNER'S VIEW & Function/How & Business process model \\
& People/Who & Use Case Diagram (Fig. 5) \\
& Time/When & Event Process Chain Diagr (Fig. 6) \\
& Motivation/Why & Platform Rules \\
Level 3 System Model & Data/What & Class Diagram (Fig. 7) \\
DESIGNER'S VIEW & Function/How & Activity Diagram (Fig. 8) \\
& Time/When & State Diagram (Fig. 9) \\
\hline
\end{tabular}

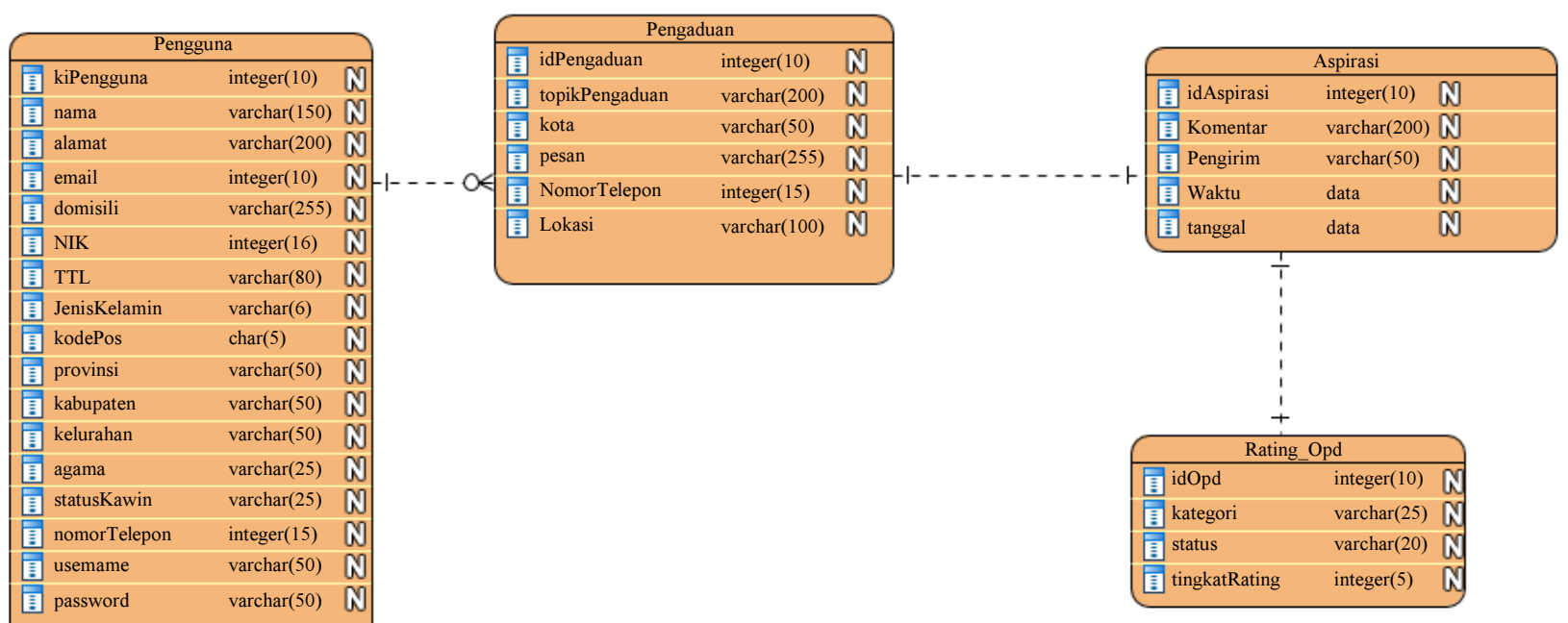

Fig. 4: Entity relationship diagram 


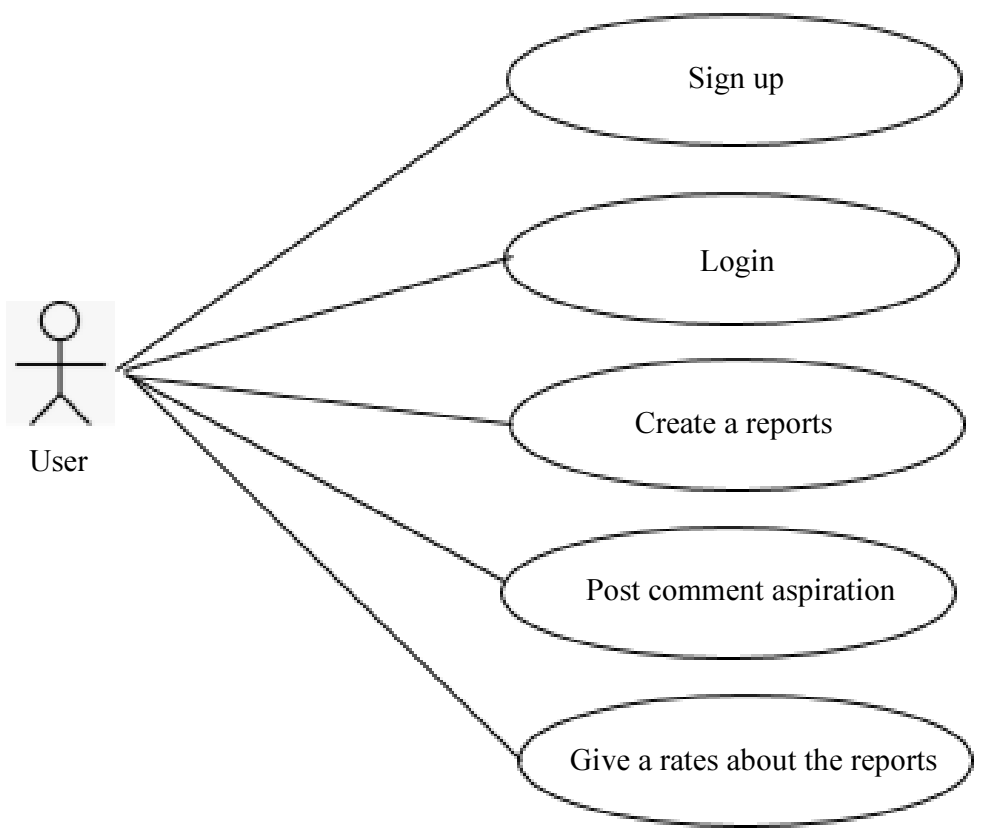

Fig. 5: Use case diagram

\section{Build and Develop: Blueprints Used for Prototyping}

In this phase, artifacts are used with the appropriate context to solve the problem in building social mediabased e-government application. According to (Peffers, 2007), this can be taken from experiments, case studies, or other appropriate points. In this study, the platform was built based on interviews with related officials and was an improvement of the artifact design from the previous stage that is used as blueprints. This prototype is considered as simplified version that is implemented from the system features that want to be developed quickly and used for early evaluation (Sabale and Dani, 2012). According to (Scacchi, 2001), prototypes take from architecture, design, features and system functions as inputs and are tested through prototype implementation.

Prototype development is done by three IT practitioners who have been working in some leading software companies for two years. The application developer is done by Department of Communication and Informatics Tangerang (in-house). The development process takes eight weeks and the developer provides all the enhancements of artifacts. All major features have been implemented. Results from the prototype phase that have been implemented based on blueprints. The prototype can be used on web platform android and iOS system. The user interface is very simple and the uploaded application must use the same programming language as the prototype.

\section{Evaluation Effectiveness and Efficiency}

Artifact was observed and measured based on effectiveness and efficiency in solving problems. In this phase, the comparison between the objectives of the solution and the actual results should occur. At the end of the phase, the researcher can iterate/repeat back to the design and development stage to improve the artifact or to move on to the final stage, future research or future projects (Peffers, 2007.

To be able to test the effectiveness of blueprints in the development of social media-based e-government application, the researcher started with the test case to test every blueprint through prototype. Each blueprint was tested to find the success and failure of test case which is to be used as an evaluation for the testing committee. For example, activity diagram test produced test case to ensure the prototype has followed the appropriate sequence of designs, etc.

The test case is a specific input including a procedure that allows the tester to test the software (Keyvanpour et al., 2013). The main purpose of the test case is to detect errors in the system against the design and requirements that have been made. This test is black box testing because it is related to an external function of the platform, not the coding design and coding style (Desikan and Ramesh, 2006). The tester provides all the development of artifacts for generating test scenarios and validates the test case results. 


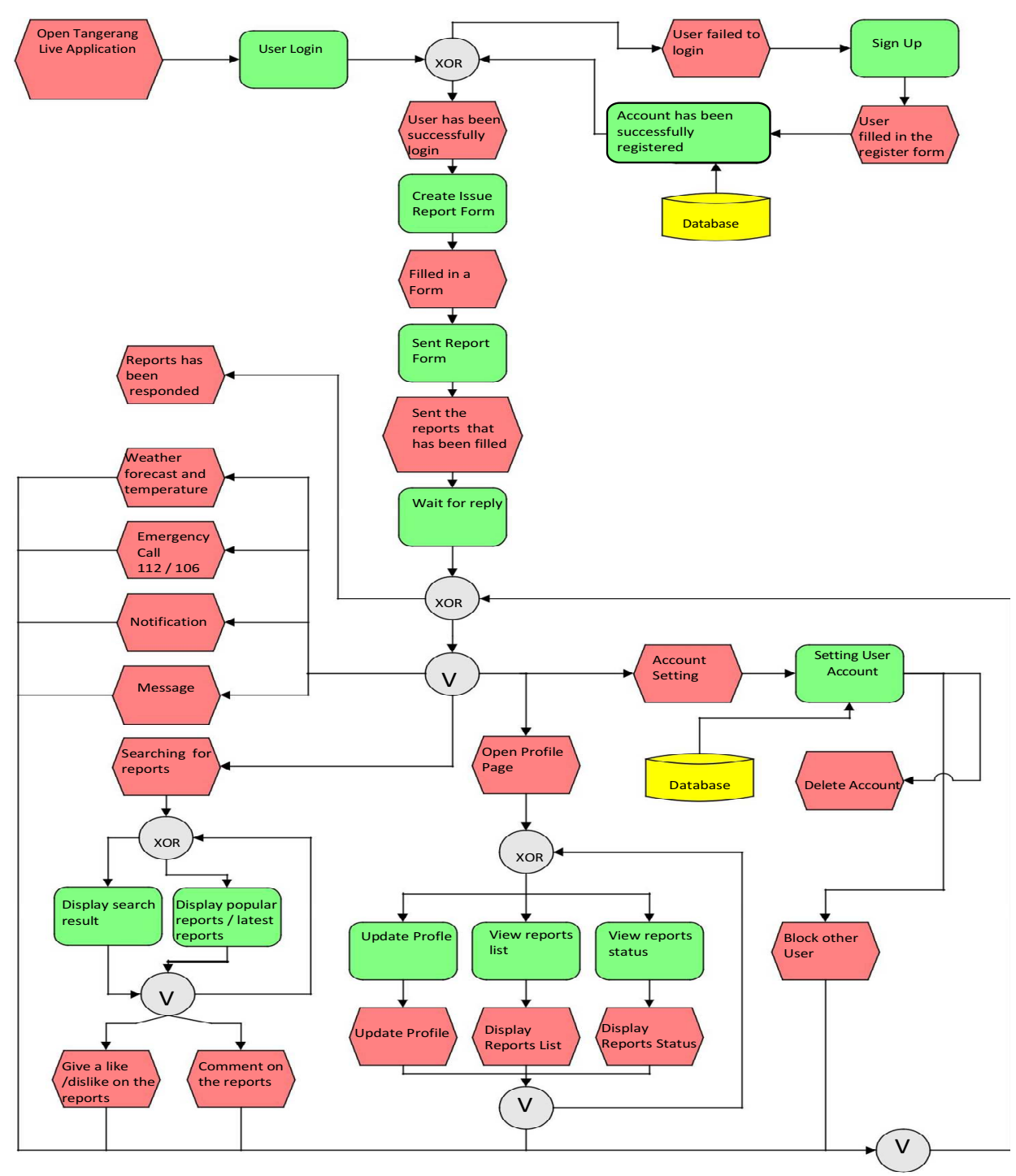

Fig. 6: Event process chain diagram

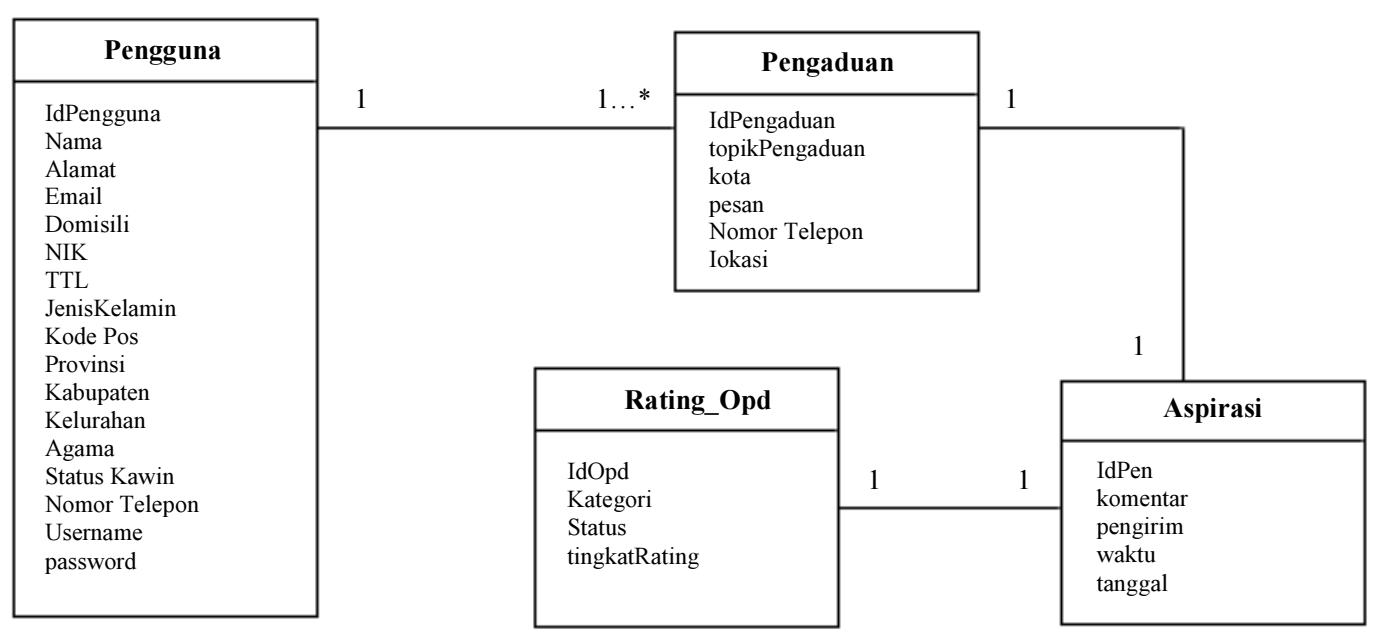

Fig. 7: Class diagram 


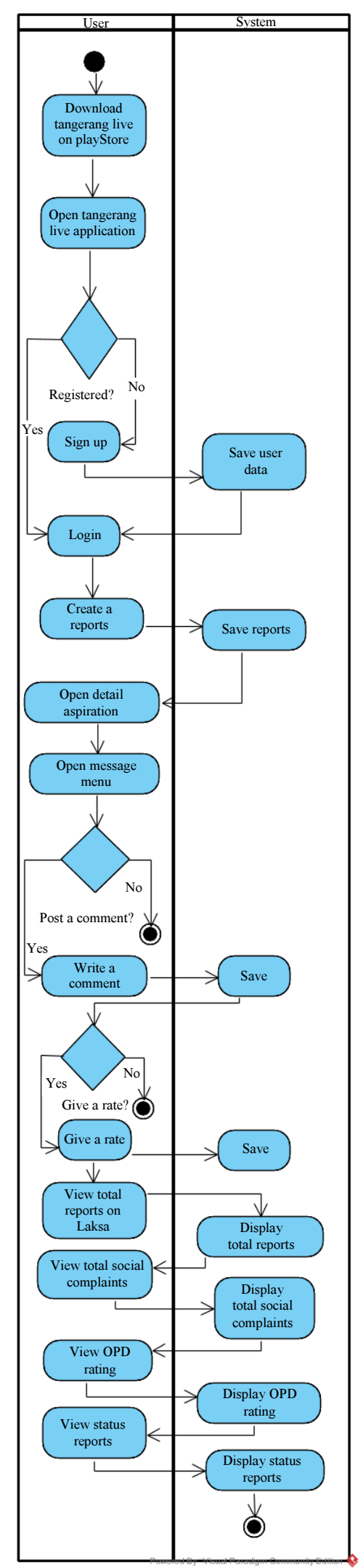

Fig. 8: Activity diagram 


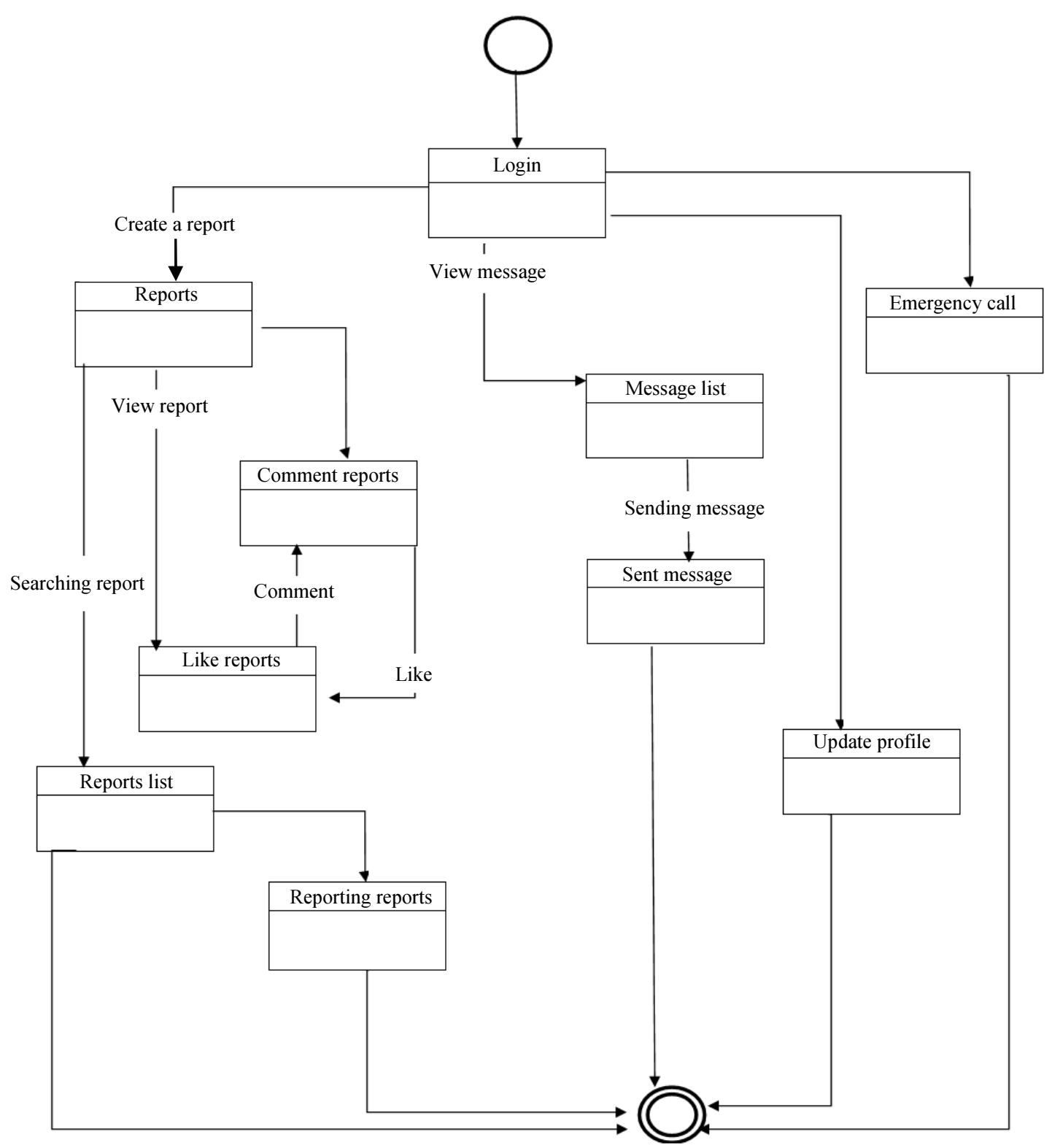

Fig. 9: State diagram

After being executed, 101 test cases were passed and 5 cases were failed. Thus, the pass rate is calculated to identify the percentage of test cases that passed the test. It reflected the quality of the software being implemented and the extent to which it has been following the objectives and design. Since the grade of test case was above $90 \%$ then it can be claimed that this is acceptable in most software development projects (Desikan and Ramesh, 2006), the graduation rates that are exceeding $90 \%$ are considered satisfying.

\section{Discussion}

Problems, artifact developments and capabilities in the completion must be communicated to researchers, professionals, stakeholders and citizens. This research has been communicated in the form of research problems, prototype and evaluation results to the chosen citizen, including academics and government officials in charge of e-Government in Tangerang, Indonesia with a purpose to implement ICT and improve existing egovernment. The government should begin to consider the social media-based e-government and should take an initiative that involves stakeholders, planners, builders and citizens. A similar study was conducted in Egypt by Mai Abu-El Seoud and Ralf Klischewski in 2015.

During interview, the official of Department of Communications and Informatics Tangerang was very interested and serious about this project. They admitted 
that this project is what they need regarding the public involvement and public participation. After the discussion of government readiness on research artifacts, several prerequisites must be completed before implementing the technology. Those are (a) the current regulation of the development of government services is carried out independently and not centralized; (b) the availability of government's open data for the community is considered as a preliminary step before implementing the application. However, it still needs many efforts to achieve it; and (c) the availability of skilled people that can develop and test social the social media-based e-government application that can be achieved through cooperation with universities, research centers and software development starts up.

\section{Conclusion}

After evaluating the existing literature relating the concept and identifying the research gap, this research has developed the architecture required for the development of social media-based e-government application. The architecture is validated and demonstrated by implementing prototype with social media application by Department of Communications and Informatics and society. Test cases were developed and applied to evaluate the effectiveness of blueprint based on prototype and questionnaire implementations. In the final stages, this study has been communicated to Department of Communications and Informatics Tangerang to identify the success factors of platform utilization.

The contribution of this research is (a) validation: Demonstrated, tested and communicated to develop a social media-based e-government application. Validation involves 9 programmers from Tangerang City Government and 51 users (citizen).; (b) Prototype development: The proposed architecture can improve the ability of social media-based e-government applications; (c) test case can be used as a reference base to test the function of the platform as a whole. In fact, suggestions from the government can be used as inputs to develop actions plans and roadmaps in implementation phase; and (d) Zachman framework can be used to develop and categorize the architecture of social media based e-government applications through a systematic approach for generating social mediabased e-government solutions.

The further research should answer the following question: How to integrate application development that available in Department of Communications and Informatics in each city and regency in Indonesia? How to publish social media-based e-government applications linked to government public databases? Which social media-based e-government test is suitable? What is the role of architecture in developing, deploying and managing social media-based e-government solutions?
In the transition from e-government (citizen as customer) to We-government (citizen as partner, people can witness the birth of 'new era' (Long, 2002) in which people put greater trust in government and government empowers people to play a much more active role in the government. This is an elaboration between the community as a service user and the government as a service provider. Under this new arrangement, the government will continue to provide regulatory, platform and access to citizens and society in taking over broader responsibilities.

\section{Acknowledgment}

This research is supported by Doctoral Study of Computer Science, Bina Nusantara University.

Thanks to Yogi, Ardian, Stevanus and Harley for developing the prototype.

\section{Authors Contribution}

Evaristus Didik Madyatmadja: Lead research project, coordinate developer, doing experiment, be an instructor, data analysis and writing the manuscript.

Edi Abdurachman: Advise research project, design the experiment, data analysis and writing manuscript.

Ford Lumban Gaol: Advise research project, design the application, data analysis, writing manuscript, proof reading.

Bonifasius Wahyu Pudjianto: Advise research project, design the research methodology, data analysis, writing manuscript, proof reading.

\section{Ethics}

Authors confirm that this manuscript has not been published elsewhere and that no ethical issues are involved.

\section{Conflict of Interest Declaration}

Authors declare that there is no conflict of interest regarding the publication of this manuscript.

\section{References}

Atari, S., M. Stewart-Week and J. McCalla, 2011. Web 2.0 in next-generation government and governance a middle east point of view. Cisco Internet Business Solutions Group (IBSG).

Baek, E.O., K. Cagiltay, E. Boling and T. Frick, 2008. User-Centered Design and Development. In: Handbook of Research on Educational Communications and Technology, Spector, J.M., M.D. Merrill, J. van Merriënboer and M.P. Driscoll, (Eds.), Routledge, ISBN-10: 1135596913, pp: 660-668.

Bagaeen, S.G., 2006. Redeveloping former military sites: Competitiveness, urban sustainability and public participation. Cities, 23: 339-352.

DOI: 10.1016/j.cities.2006.05.002 
Bridge, C., 2012. Citizen centric service in the Australian department of human services: The department's experience in engaging the community in co-design of government service delivery and developments in e-government services.

Centeno, C., R. van Bavel and J.C. Burgelman, 2005. A prospective view of e-government in the European Union. Electr. J. E-Gov., 3: 59-66.

DC, 2007. The double diamond design process model. Design Council.

Desikan, S. and G. Ramesh, 2006. Software Testing: Principles and Practice. 1st Edn., Pearson Education, India, ISBN-10: 817758121X, pp: 480.

Ertaul, L. and R. Sudarsanam, 2005. Security planning using Zachman framework for enterprises. Proceedings of the EURO mGOV, (mGOV' -5), pp: 153-162.

Gupta, D.N., 2007. Citizen-centric approach for egovernance. Institute of Social Sciences (ISS).

Hardjaloka, L., 2014. Studi penerapan e-government di indonesia dan negara lainnya sebagai solusi pemberantasan korupsi di sektor publik. Rechtsvinding, 3: 435-452.

Hevner, A.R., S.T. March, J. Park and S. Ram, 2004. Design science in information systems research. Mis Quarterly, 28: 75-105. DOI: 10.2307/25148625

Keyvanpour, M.R., H. Homayouni and H. Shirazee, 2013. A classification framework for automatic test case generation techniques for web applications. J. Inform. Process. Manage., 4: 26-39.

Khasawneh, R.T. and E.A. Abu-Shanab, 2013. Egovernment and social media sites: The role and impact. World J. Comput. Applic. Terchnol., 1: 10-17. DOI: $10.13189 /$ wjcat.2013.010103

Kuswinardi, W., 2011. Pembuatan kakas pengukuran kinerja layanan e-government dengan metode extended goal question metric.

Long, M., 2002. Beyond traditional boundaries: Government in the information age. Australian J. Public Admin., 61: 3-12. DOI: $10.1111 / 1467-8500.00253$

March, S.T. and G.F. Smith, 1995. Design and natural science research on information technology. Dec. Support Syst., 15: 251-266.

DOI: 10.1016/0167-9236(94)00041-2
Mustafid and A. Sugiharto, 2014. Analisa implementasi e-government untuk pelayanan publik di kota semarang. Riptek, 8: 35-50.

Nunamaker, J., 1990. Systems development in information systems research. Proceedings of the 23th Annual Hawaii International Conference on System Sciences, Jan. 2-5, IEEE Xplore Press, Kailua-Kona, HI, USA, pp: 631-640. DOI: $10.1109 / \mathrm{HICSS} .1990 .205401$

Peffers, K., 2007. A design science research methodology for information systems research. J. Manage. Infrom. Syst., 24: 45-77. DOI: $10.2753 / \mathrm{MIS} 0742-1222240302$

Prabowo, M.A., 2016. No Title. Info Komputer.

Pusbindiklatren, B., 2015. Badan perencanaan pembangunan nasional republik Indonesia.

Roy, D., 2014. Role of social media in e-government. New Man Int. J. Multidisciplinary Stud., 1: 50-54.

Sabale, R.G. and A.R. Dani, 2012. Comparative study of prototype model for software engineering with system development life cycle. IOSR J. Eng., 2: 21-24.

Saha, P., 2008. Government e-service delivery: Identification of success factors from citizens' perspective. $\mathrm{PhD}$ Thesis, Luleå University of Technology.

Scacchi, W., 2001. Process models in software engineering. Encyclopedia of Software Engineering.

Takeda, H., P. Veerkamp and H. Yoshikawa, 1990. Modeling design process. AI Magazine, 11: 37.

Tamm, T., P.B. Seddon, G. Shanks and P. Reynolds, 2011. How does enterprises architecture add value to organisations? Commun. Assoc. Inform. Syst., 28: 141-168.

TWH, 2011. The Obama's administration commitment to open government: status report. The White House.

Vaishnavi, V.K. and W. Kuechler, 2004. Design research in information systems.

Wirmansyah, A., 2018. https://nonstopnews.id/KotaTangerang/details/412/Pelayanan-Publik-KotaTangerang-dalam-Satu-Genggaman

Zachman, J., 1987. A framework for information systems architecture. IBM Syst. J., 26: 276-292. DOI: $10.1147 /$ sj.263.0276 